Artur Myśliwiec ${ }^{1}$, Przemysława Jarosz-Chobot² ${ }^{2}$ Małgorzata Myśliwiec ${ }^{3}$, Krzysztof Strojek ${ }^{4}$, Paweł Piątkiewicz ${ }^{5}$, Mieczysław Walczak ${ }^{6}$, Władysław Grzeszczak Beata Koń ${ }^{8}$, Milena Kozioł ${ }^{8}$, Barbara Więckowska ${ }^{8}$

${ }^{1}$ Gdansk University of Physical Education and Sport, Poland

${ }^{2}$ Department of Children's Diabetology, School of Medicine in Katowice, Medical University of Silesia in Katowice, Poland

${ }^{3}$ Department of Paediatrics, Diabetology and Endocrinology, Medical University of Gdańsk, Poland

${ }^{4}$ Department of Internal Diseases Diabetology and Cardiometabolic Diseases, School of Medicine with the Division of Dentistry (SMDZ) in Zabrze, Medical University of Silesia, Katowice, Poland

${ }^{5}$ Department of Internal Diseases, Diabetology and Endocrinology, Medical University of Warsaw, Poland

${ }^{6}$ Department of Pediatrics, Endocrinology, Diabetology, Metabolic Diseases and Cardiology of the Developmental Age, Pomeranian Medical University, Szczecin, Poland

${ }^{7}$ Department of Internal Medicine, Diabetology and Nephrology, School of Medicine with the Division of Dentistry in Zabrze, Medical University of Silesia in Katowice, Poland

${ }^{8}$ Department of Analysis and Strategy, Ministry of Health, Collegium of Economic Analysis, Warsaw School of Economics, Poland

\title{
Accessibility to personal insulin pumps among children with diabetes mellitus in Poland in 2014
}

\section{ABSTRACT}

One of the principal aspects of comprehensive medical care for patients with diabetes mellitus, especially paediatric patients, is the accessibility to personal insulin pumps. In Poland, the National Health Fund secures personal insulin pumps for children by means of a separately commissioned service. The structure of the provided services varies greatly from province to province in terms of accessibility to insulin pumps. (Clin Diabetol 2018; 7, 4: 175-181)

Key words: paediatric diabetes care, personal insulin pumps, diabetes

\section{Introduction}

One of the principal aspects of contemporary medical care for paediatric patients with diabetes mellitus

\section{Address for correspondence:}

mgr Artur Myśliwiec

Zakład Fizjologii Sportu

Akademii Wychowania Fizycznego i Sportu

ul. Kazimierza Górskiego 1, 80-336 Gdańsk

e-mail: admysliwiec@wp.pl

Clinical Diabetology 2018, 7, 4, 175-181

DOI: $10.5603 /$ DK.2018.0018

Received: 05.06.2018

Accepted: 27.06.2018 is the accessibility to modern technologies, including personal insulin pumps.

The most common type of diabetes mellitus occurring in the paediatric population is type 1 diabetes mellitus ( $98 \%$ of the cases), whose treatment, in all the patients, requires administration of insulin according to an intensive insulin therapy regimen [1]. According to what is currently known, the most effective treatment for type 1 diabetes mellitus patients is intensive insulin therapy with a personal insulin pump [2-4]. Numerous study results unequivocally demonstrate that, compared to multiple daily injections, treatment with the insulin pump is more beneficial and more effective in achieving good metabolic control and ensures a better quality of life to the patients as a result of a higher precision in insulin dosing, convenient self-administration of insulin in public places, a significantly lower number of insulin injections, a lower risk of hypoglycemia and glucose fluctuations, adjustment of an insulin dose to match the composition of a meal, an easier adjustment of an insulin dose to match the level of physical activity, a precise modelling of the basal dose according to the current needs [5-7].

Treatment with insulin pumps providing continuous subcutaneous insulin infusion has been available to children with diabetes mellitus in Poland for more than 15 years. The first personal insulin pumps were 
introduced and widely popularised for children by the Great Orchestra of Christmas Charity Foundation (WOŚP, Wielka Orkiestra Świątecznej Pomocy) in 2001. Another milestone was the introduction of the service "treatment with an insulin pump" by the National Health Fund in 2008 to the catalogue of public-funded services under separately commissioned healthcare services. Initially, the service was only available to children but in 2011 also young adults up to 26 years of age were included in the eligible population [8-10]. Given that paediatric diabetes care is centralised, it is usually the case that only one regional diabetes care facility per province provides treatment with insulin pumps.

The aim is to analyze the accessibility to personal insulin pumps reimbursed by the National Health Fund in the paediatric population in Poland in 2014.

\section{Material and methods}

The starting point for this study were the maps of health needs in diabetes mellitus published in 2016 by the Analyses and Strategies Department, Ministry of Health, as part of the project entitled: "Maps of Health Needs: A Systemic and Implementation Analyses Base" co-financed by the European Union from the European Social Fund as part of the Operational Programme Knowledge Education Development (project number POWR.05.02.00-00-0149/15-01). This study used the definitions of variables and indicators used in the Maps of Health Needs and is an extension of the data published therein. In addition, similarly to the Maps of Health Needs, the National Health Fund individual reporting data from 2014 were used in the present study.

The analysis covered services provided to children and adolescents up to 18 years of age. The study population was divided into 3 age groups: 0-6, 7-14 and 15-18 years. The patient's age was defined according to the year of birth.

The analysis provides statistics on personal insulin pumps implanted in children with diabetes mellitus in Poland in 2014. The reported pump implantation was defined as product 5.10.00.0000053 (treatment of diabetes mellitus with an insulin pump in children up to 6 years of age or requiring up to 20 units of insulin daily) or as product 5.10.00.0000054 (treatment of diabetes mellitus with an insulin pump in children from 6 to 18 years of age) reported under separately commissioned services. The publication presents a set of descriptive statistics at the national and provincial levels. The analyses were carried out using $\mathrm{R}$ (a software for statistics) (Table 1).

The analysis also provides information about insulin pump implantation in new patients. New patients were defined in the present study as patients below 18 years of age who, during the period from 2009 to 365 days prior to the commencement of services aimed to implant an insulin pump, had not been provided by the public healthcare system with any service as part of outpatient specialist care or inpatient care for diabetes mellitus [ICD-10 (International Statistical Classification of Diseases and Related Health Problems, 10th edition) codes E10-E15] [13] (Table 2-4).

\section{Results}

In Poland, in 2014, a total of 1.7 thousand personal insulin pumps were implanted; 25 per 100,000 children (Figure 1). The number of pumps per 100,000 children (according to the patient's place of residence) was the lowest in the Małopolskie Province (14.0) and the highest in the Świętokrzyskie and Mazowieckie Provinces (35.3 and 33.4, respectively). As shown in Table 5, 136 patients migrated outside their province of residence in order to receive an insulin pump. The largest number of patients from other provinces arrived in the Śląskie and Mazowieckie Provinces. Patients from other provinces accounted for $18 \%$ and $14 \%$, respectively, of all the children in these two provinces who were implanted with an insulin pump. A total of $46 \%$ of all insulin pumps in Poland were implanted in first-time patients. In two provinces, the Świętokrzyskie and Podlaskie Provinces, this percentage exceeded $60 \%$. The percentage of insulin pumps implanted in new patients was the highest in the age group 0-6 years (88\%) and the lowest in the age group $15-18$ years (24\%).

\section{Discussion}

Modern technologies in diabetes care, treatment with personal insulin pumps, have dramatically changed the effectiveness and safety of insulin treatment, especially in children with diabetes mellitus [5-7]. Unfortunately, given that they require the provision of appropriate highly specialized care, advanced technologies are usually more accessible in larger and dynamic diabetes care facilities. This is associated with the numerous requirements related to insulin pump therapy (including, among other things, the reading and interpretation of data saved in the pump memory, systems for glucose monitoring, wide access to specialist diabetes education programmes). The worldwide trend in line with evidence-based medicine is to popularize insulin pump therapy in children [5-7].

In Poland, the number of children with diabetes mellitus receiving insulin pump therapy was estimated at 6.1 thousand, which accounts for about $63 \%$ of all the children with diabetes mellitus in 2014 (according to data from the National Health Fund database of inpatient services and appointments with specialists). 
Table 1. Insulin pumps implanted in children, in total and by age group, according to the place of residence

\begin{tabular}{|c|c|c|c|c|}
\hline \multirow[t]{2}{*}{ Province } & \multicolumn{4}{|c|}{$\begin{array}{l}\text { Number of insulin pumps implanted under separately commissioned healthcare services } \\
\qquad \text { (according to the place of residence) }\end{array}$} \\
\hline & Total & Age group 0-6 & Age group 7-14 & Age group 15-18 \\
\hline Dolnośląskie & 102 & 15 & 58 & 29 \\
\hline Kujawsko-pomorskie & 70 & 14 & 37 & 19 \\
\hline Lubelskie & 88 & 8 & 58 & 22 \\
\hline Lubuskie & 42 & 10 & 21 & 11 \\
\hline Łódzkie & 132 & 22 & 67 & 43 \\
\hline Małopolskie & 90 & 24 & 48 & 18 \\
\hline Mazowieckie & 330 & 67 & 182 & 81 \\
\hline Opolskie & 32 & 5 & 22 & 5 \\
\hline Podkarpackie & 58 & 13 & 33 & 12 \\
\hline Podlaskie & 57 & 15 & 30 & 12 \\
\hline Pomorskie & 104 & 33 & 54 & 17 \\
\hline Śląskie & 170 & 49 & 90 & 31 \\
\hline Świętokrzyskie & 76 & 11 & 44 & 21 \\
\hline Warmińsko-mazurskie & 86 & 11 & 57 & 18 \\
\hline Wielkopolskie & 192 & 28 & 100 & 64 \\
\hline Zachodniopomorskie & 75 & 15 & 46 & 14 \\
\hline Poland & 1704 & 340 & 947 & 417 \\
\hline
\end{tabular}

Table 2. Insulin pumps implanted in children (age group 0-6), in total and according to province: according to the place of residence, for patients from outside the province and for patients newly diagnosed with diabetes mellitus

\begin{tabular}{lccc}
\hline Province & $\begin{array}{c}\text { Number of insulin pumps } \\
\text { implanted under separately } \\
\text { commissioned healthcare } \\
\text { services (according to the place } \\
\text { of service provision) for the } \\
\text { age group 0-6 }\end{array}$ & $\begin{array}{c}\text { Percentage of insulin pumps } \\
\text { implanted in patients from } \\
\text { outside the province for the } \\
\text { age group 0-6 }\end{array}$ & $\begin{array}{c}\text { Percentage of insulin pumps } \\
\text { implanted in new patients } \\
\text { (within one year of appearing } \\
\text { in the system) for the } \\
\text { age group 0-6 }\end{array}$ \\
\hline Dolnośląskie & 12 & $0 \%$ & $67 \%$ \\
Kujawsko-pomorskie & 24 & $12 \%$ & $92 \%$ \\
Lubelskie & 53 & $8 \%$ & $87 \%$ \\
Lubuskie & 11 & $9 \%$ & $91 \%$ \\
tódzkie & 26 & $4 \%$ & $77 \%$ \\
Małopolskie & 33 & $6 \%$ & $88 \%$ \\
Mazowieckie & 16 & $6 \%$ & $94 \%$ \\
Opolskie & 12 & $0 \%$ & $58 \%$ \\
Podkarpackie & 5 & $0 \%$ & $100 \%$ \\
Podlaskie & 8 & $12 \%$ & $100 \%$ \\
Pomorskie & 23 & $4 \%$ & $78 \%$ \\
Śląskie & 16 & $12 \%$ & $100 \%$ \\
Świętokrzyskie & 11 & $0 \%$ & $100 \%$ \\
Warmińsko-mazurskie & 11 & $0 \%$ & $91 \%$ \\
Wielkopolskie & 76 & $8 \%$ & $92 \%$ \\
Zachodniopomorskie & 340 & $800 \%$ \\
Poland & & 0 & $17 \%$ \\
\hline
\end{tabular}


Table 3. Insulin pumps implanted in children (age group 7-14), in total and according to province: according to the place of residence, for patients from outside the province and for patients newly diagnosed with diabetes mellitus

\begin{tabular}{|c|c|c|c|}
\hline Province & $\begin{array}{l}\text { Number of insulin pumps } \\
\text { implanted under separately } \\
\text { commissioned healthcare } \\
\text { services (according to the place } \\
\text { of service provision) for the } \\
\text { age group 7-14 }\end{array}$ & $\begin{array}{l}\text { Percentage of insulin pumps } \\
\text { implanted in patients from } \\
\text { outside the province for the } \\
\text { age group } 7-14\end{array}$ & $\begin{array}{l}\text { Percentage of insulin pumps } \\
\text { implanted in new patients } \\
\text { (within one year of appearing } \\
\text { in the system) for the } \\
\text { age group 7-14 }\end{array}$ \\
\hline Dolnośląskie & 35 & $14 \%$ & $51 \%$ \\
\hline Kujawsko-pomorskie & 67 & $9 \%$ & $33 \%$ \\
\hline Lubelskie & 117 & $23 \%$ & $45 \%$ \\
\hline Lubuskie & 45 & $4 \%$ & $33 \%$ \\
\hline Łódzkie & 96 & $5 \%$ & $29 \%$ \\
\hline Małopolskie & 51 & $0 \%$ & $49 \%$ \\
\hline Mazowieckie & 58 & $5 \%$ & $36 \%$ \\
\hline Opolskie & 37 & $3 \%$ & $41 \%$ \\
\hline Podkarpackie & 44 & $2 \%$ & $27 \%$ \\
\hline Podlaskie & 19 & $0 \%$ & $74 \%$ \\
\hline Pomorskie & 24 & $4 \%$ & $17 \%$ \\
\hline Śląskie & 47 & $6 \%$ & $51 \%$ \\
\hline Świętokrzyskie & 32 & $3 \%$ & $72 \%$ \\
\hline Warmińsko-mazurskie & 55 & $2 \%$ & $42 \%$ \\
\hline Wielkopolskie & 202 & $12 \%$ & $44 \%$ \\
\hline Zachodniopomorskie & 18 & $6 \%$ & $39 \%$ \\
\hline Poland & 947 & $9 \%$ & $41 \%$ \\
\hline
\end{tabular}

Table 4. Insulin pumps implanted in children (age group 15-18), in total and according to province: according to the place of residence, for patients from outside the province and for patients newly diagnosed with diabetes mellitus

\begin{tabular}{|c|c|c|c|}
\hline Province & $\begin{array}{l}\text { Number of insulin pumps } \\
\text { implanted under separately } \\
\text { commissioned healthcare } \\
\text { services (according to the place } \\
\text { of service provision) for the } \\
\text { age group 15-18 }\end{array}$ & $\begin{array}{l}\text { Percentage of insulin pumps } \\
\text { implanted in patients from } \\
\text { outside the province for the } \\
\text { age group } 15-18\end{array}$ & $\begin{array}{l}\text { Percentage of insulin pumps } \\
\text { implanted in new patients } \\
\text { (within one year of appearing } \\
\text { in the system) for the } \\
\text { age group 15-18 }\end{array}$ \\
\hline Dolnośląskie & 12 & $0 \%$ & $42 \%$ \\
\hline Kujawsko-pomorskie & 41 & $0 \%$ & $17 \%$ \\
\hline Lubelskie & 38 & $18 \%$ & $26 \%$ \\
\hline Lubuskie & 21 & $0 \%$ & $43 \%$ \\
\hline Łódzkie & 62 & $5 \%$ & $21 \%$ \\
\hline Małopolskie & 16 & $6 \%$ & $38 \%$ \\
\hline Mazowieckie & 32 & $12 \%$ & $16 \%$ \\
\hline Opolskie & 17 & $6 \%$ & $12 \%$ \\
\hline Podkarpackie & 14 & $7 \%$ & $21 \%$ \\
\hline Podlaskie & 11 & $9 \%$ & $27 \%$ \\
\hline Pomorskie & 11 & $0 \%$ & $18 \%$ \\
\hline Śląskie & 14 & $7 \%$ & $29 \%$ \\
\hline Świętokrzyskie & 12 & $0 \%$ & $17 \%$ \\
\hline Warmińsko-mazurskie & 17 & $0 \%$ & $29 \%$ \\
\hline Wielkopolskie & 95 & $15 \%$ & $25 \%$ \\
\hline Zachodniopomorskie & 4 & $0 \%$ & $25 \%$ \\
\hline Poland & 417 & $9 \%$ & $24 \%$ \\
\hline
\end{tabular}




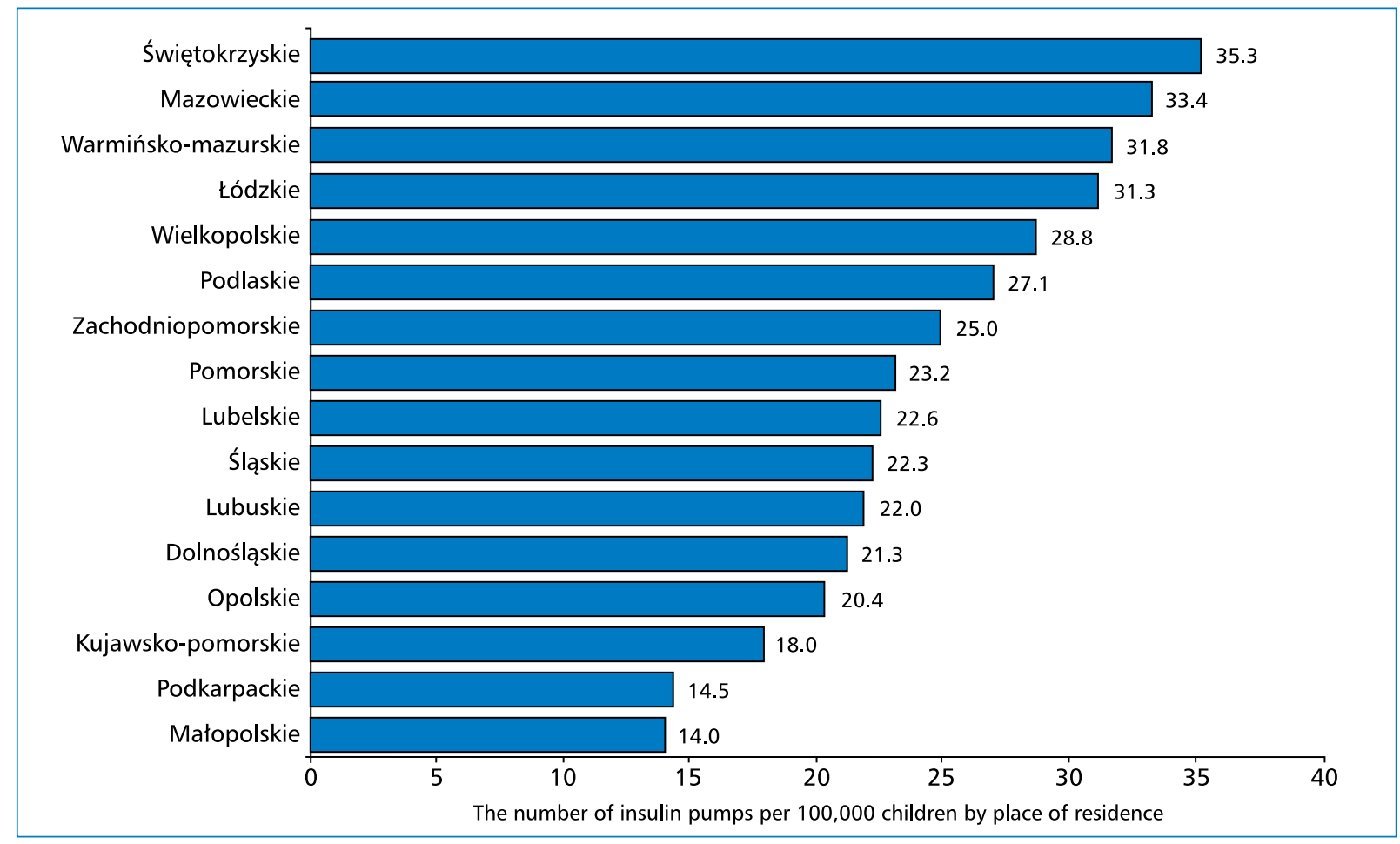

Figure 1. Number of insulin pumps per 100.000 children that were implanted under separately commissioned healthcare services, according to province

Table 5. Insulin pumps implanted in children, in total and according to province: according to the place of service provision, for patients from outside the province and for patients newly diagnosed with diabetes mellitus

\begin{tabular}{lccc}
\hline Province & $\begin{array}{c}\text { Number of insulin pumps } \\
\text { implanted under separately } \\
\text { commissioned healthcare } \\
\text { services (according to the } \\
\text { place of service provision) }\end{array}$ & $\begin{array}{c}\text { Percentage of insulin pumps } \\
\text { implanted in patients from } \\
\text { outside the province }\end{array}$ & $\begin{array}{c}\text { Percentage of insulin pumps } \\
\text { implanted in new patients } \\
\text { (within one year of appearing } \\
\text { in the system) }\end{array}$ \\
\hline Dolnośląskie & 106 & $8 \%$ & $53 \%$ \\
Kujawsko-pomorskie & 66 & $3 \%$ & $39 \%$ \\
Lubelskie & 63 & $3 \%$ & $52 \%$ \\
Lubuskie & 38 & $5 \%$ & $44 \%$ \\
tódzkie & 132 & $7 \%$ & $33 \%$ \\
Małopolskie & 58 & $3 \%$ & $60 \%$ \\
Mazowieckie & 373 & $14 \%$ & $39 \%$ \\
Opolskie & 25 & $4 \%$ & $36 \%$ \\
Podkarpackie & 55 & $2 \%$ & $32 \%$ \\
Podlaskie & 59 & $2 \%$ & $66 \%$ \\
Pomorskie & 100 & $3 \%$ & $41 \%$ \\
Śląskie & 208 & $18 \%$ & $57 \%$ \\
Świętokrzyskie & 77 & $4 \%$ & $65 \%$ \\
Warmińsko-mazurskie & 83 & $1 \%$ & $46 \%$ \\
Wielkopolskie & 184 & $5 \%$ & $49 \%$ \\
Zachodniopomorskie & 77 & $8 \%$ & $44 \%$ \\
Poland & 1704 & $8 \%$ & $46 \%$ \\
\hline
\end{tabular}


The popularization of this treatment model is closely associated with reimbursement of both the insulin pump and the accessories. This reimbursement, both in Poland and other countries, progressed gradually and included various indications [5-7, 11-13].

Interestingly, there are considerable differences in the number of insulin pumps in children between individual regions of Poland. The number of insulin pumps per 100,000 children considerably varies from province to province, and in 2014, there was a 2.5 -fold difference between the provinces. The unequal accessibility is also evidenced by the number of patients migrating to the Śląskie and Mazowieckie Provinces. The percentage of insulin pumps implanted within one year of appearing in the system since 2009 with the diagnosis of diabetes mellitus (it should be assumed that these are children with newly diagnosed diabetes mellitus) was $46 \%$. Disturbingly low percentages were observed in several provinces, mainly in the Podkarpackie and Łódzkie Provinces. The regional differences between individual diabetes care facilities are most likely multifactorial. Firstly, the regional branches of the National Health Fund differently commission separately commissioned services for children with diabetes mellitus at facilities that provide such services. There is a lack of standards that would determine the number of insulin pumps for children with diabetes mellitus for a given province, hence the service commissioning is often "blind". Further difficulties are posed by the fact that insulin pumps in public facilities are purchased by means of tenders, the possession of experienced and committed specialist diabetes team, and the possession of appropriate equipment at the diabetes care facility. Unfortunately, although not only in Poland, the differences between individual diabetes care facilities are often still quite considerable $[9,10]$. Elimination of the differences between individual diabetes care facilities requires an appropriate strategy (e.g. central determination of glycated haemoglobin) and the formation of large paediatric diabetes care facilities that could meet the economic requirements, mainly with respect to staff and equipment. Improving the accessibility to insulin pump therapy is without any doubt an important challenge. One of the fastest solutions would be to estimate the percentage of pumps requiring commissioning in individual provinces per specific number of children with diabetes mellitus. This requires determining the number of children with diabetes mellitus in each province, which would be made possible by a registry.

The widespread use of social media nowadays suggests an additional important aspect. Patients and their caregivers look for the best diabetes care and the most recent versions of the devices offered: the insulin pumps. This is another aspect that is partially responsible for the "pump migration" and should lead to appropriate identification and rewarding of the leading diabetes care facilities.

\section{Conclusions}

Accessibility to personal insulin pumps among children with diabetes mellitus in Poland varies.

Equal access to treatment with personal insulin pumps should be a priority when developing programs supporting the treatment of diabetes mellitus and should be an important element of health policy in Poland.

\section{REFERENCES}

1. Chobot A, Polanska J, Brandt A, et al. Updated 24-year trend of Type 1 diabetes incidence in children in Poland reveals a sinusoidal pattern and sustained increase. Diabet Med. 2017; 34(9): 1252 -1258, doi: 10.1111/dme.13345, indexed in Pubmed: 28257151.

2. Steineck I, Cederholm J, Eliasson B, et al. Swedish National Diabetes Register. Insulin pump therapy, multiple daily injections, and cardiovascular mortality in 18,168 people with type 1 diabetes: observational study. BMJ. 2015; 350: h3234, doi: 10.1136/bmj. h3234, indexed in Pubmed: 26100640.

3. Benkhadra K, Alahdab F, Tamhane SU, et al. Continuous subcutaneous insulin infusion versus multiple daily injections in individuals with type 1 diabetes: a systematic review and meta-analysis. Endocrine. 2017; 55(1): 77-84, doi: 10.1007/s12020-016-1039-x, indexed in Pubmed: 27477293.

4. Bolderman KM. Putting Your Patients on the Pump. Initiation and Maintenance Guidelines. American Diabetes Association, Aleksandria. (VA): 2013

5. Danne T, Bangstad HJ, Deeb L, et al. International Society for Pediatric and Adolescent Diabetes. ISPAD Clinical Practice Consensus Guidelines 2014. Insulin treatment in children and adolescents with diabetes. Pediatr Diabetes. 2014; 15 Suppl 20: 115-134, doi: 10.1111/pedi.12184, indexed in Pubmed: 25182312.

6. Pickup JC, Sutton AJ. Severe hypoglycaemia and glycaemic control in Type 1 diabetes: meta-analysis of multiple daily insulin injections compared with continuous subcutaneous insulin infusion. Diabet Med. 2008; 25(7): 765-774, doi: 10.1111/j.14645491.2008.02486.x, indexed in Pubmed: 18644063.

7. Thabit H, Hovorka R. Continuous subcutaneous insulin infusion therapy and multiple daily insulin injections in type 1 diabetes mellitus: a comparative overview and future horizons. Expert Opin Drug Deliv. 2016; 13(3): 389-400, doi: 10.1517/17425247.2016.1115013, indexed in Pubmed: 26618219.

8. Zarządzenie Prezesa Narodowego Funduszu Zdrowia $\mathrm{Nr}$ 106/2008/DSOZ z dnia 26 listopada 2008 r. w sprawie określenia warunków zawierania i realizacji umów w rodzaju świadczenia zdrowotne kontraktowane odrębnie.

9. Zarządzenie Prezesa Narodowego Funduszu Zdrowia Nr 67/2011/ /DSOZ z dnia 18 października 2011 r. w sprawie określenia warunków zawierania i realizacji umów w rodzaju świadczenia zdrowotne kontraktowane odrębnie.

10. Centrum Systemów Informacyjnych Ochrony Zdrowia, (2008) Międzynarodowa Statystyczna Klasyfikacja Chorób i Problemów Zdrowotnych. Rewizja dziesiąta Tom I. 
11. Steineck I, Cederholm J, Eliasson B et al. Swedish National Diabetes Register. Insulin pump therapy, multiple daily injections, and cardiovascular mortality in 18,168 people with type 1 diabetes: observational study. BMJ. 2015; 350: h3234, doi: 10.1136/bmj. h3234, indexed in Pubmed: 26100640.

12. de Beaufort CE, Swift PGF, Skinner CT, et al. Hvidoere Study Group on Childhood Diabetes 2005. Continuing stability of center differences in pediatric diabetes care: do advances in diabetes treatment improve outcome? The Hvidoere Study Group on Childhood Diabetes. Diabetes Care. 2007; 30(9): 2245-2250, doi: 10.2337/dc07-0475, indexed in Pubmed: 17540955.

13. https://www.wosp.org.pl/medycyna/programy/cukrzyca-dzieci. (08.05.2018) 